\title{
Alterations in AMPA Receptor Subunit Expression after Experimental Spinal Cord Contusion Injury
}

\author{
Stacie D. Grossman, ${ }^{1}$ Barry B. Wolfe, ${ }^{2}$ Robert P. Yasuda, ${ }^{2}$ and Jean R. Wrathall ${ }^{1}$ \\ Departments of ${ }^{1}$ Cell Biology and ${ }^{2}$ Pharmacology, Georgetown University Medical Center, Washington, DC 20007
}

The AMPA-preferring subtype of ionotropic glutamate receptors (GluRs) is a hetero-oligomeric ion channel assembled from various combinations of four subunits: GluR1, GluR2, GluR3, and GluR4. Antagonists of these receptors can mitigate the effects of experimental spinal cord injury (SCI), indicating that these receptors play a significant role in pathophysiology after spinal trauma. We tested the hypothesis that SCI alters expression of AMPA receptors using a standardized thoracic weightdrop model of rat contusive spinal cord injury. AMPA receptor subunit expression was measured at $24 \mathrm{hr}$ and at 1 month after $\mathrm{SCl}$ with quantitative Western blot analysis and in situ hybridization. GluR2 protein levels were preferentially reduced near the injury site $24 \mathrm{hr}$ after $\mathrm{SCl}$. This reduction persisted at 1 month. At a cellular level, a significant decrease in both GluR2 and GluR4 mRNA was found in spared ventral motor neurons adjacent to the injury site and distal to it, with other AMPA subunit mRNAs maintained at control levels. In contrast, only GluR1 mRNA was decreased in the sympathetic preganglionic neurons of the intermediolateral horn. These results suggest population-specific and long-lasting changes in neuronal AMPA receptor composition, which may alter response to glutamate after SCI. These alterations may contribute not only to acute neuropathological consequences of injury, but they may also be partially responsible for the altered functional state of preserved tissue seen chronically after SCl.

Key words: AMPA receptor; spinal cord injury; excitatory amino acids; GluR2; motor neurons; rat; Western blot; in situ hybridization; antibodies
Glutamate receptors (GluRs) appear to contribute significantly to the pathology that develops in the spinal cord after traumatic injury. In models of spinal cord injury (SCI), extracellular glutamate is transiently but significantly increased after trauma (Demediuk et al., 1989; Panter et al., 1990; Liu et al., 1991) to levels that would cause degeneration of neurons in culture with cell death attributable to excessive $\mathrm{Ca}^{2+}$ and $\mathrm{Na}^{2+}$ influx through ionotropic GluRs (Choi, 1994).

Antagonists of ionotropic GluRs, administered acutely after experimental SCI, significantly reduce the long-term functional impairments that result from experimental injury (Faden and Simon, 1988; Faden et al., 1988, 1990; Gomez-Pinilla et al., 1989; von Euler et al., 1994; Wrathall et al., 1994, 1996). In particular, 2,3-dihydroxy-6-nitro-7-sulfamoyl-benzo(f)quinoxaline (NBQX) (Sheardown et al., 1990), an antagonist of the AMPA and kainate-preferring GluRs, is especially effective. NBQX reduces histopathology and functional deficits when given intravenously (Wrathall et al., 1996) or when focally administered into the injury site 15 min or 4 hr (Wrathall et al., 1994, 1997) after a standardized contusion injury of the rat thoracic spinal cord. NBQX also reduces glial cell loss and acute white matter pathology (Rosenberg et al., 1999). Furthermore, motor neurons, which are preferentially injured by intrathecal kainate (Hugon et al.,

Received Feb. 1, 1999; revised April 21, 1999; accepted April 23, 1999.

This work was supported by National Institutes of Health Grants P01 NS28130, R01 NS 37733 (J.R.W.), R01 NS 36246 (B.B.W.), and R29AA (R.P.Y.), and National Institute of Mental Health National Research Service Award 1F31MH12038-01 (S.D.G.). Special thanks to Sadia Aden for assisting with surgeries and animal care. We also thank Dr. Robert Wenthold for kindly supplying GluR2 antibody.

Correspondence should be addressed to Dr. Jean R. Wrathall, Department of Cell Biology, Georgetown University Medical Center, 3900 Reservoir Road, NW, Washington, DC 20007.

Copyright (C) 1999 Society for Neuroscience $\quad 0270-6474 / 99 / 195711-10 \$ 05.00 / 0$
1986), are protected from excitotoxin-induced degeneration by NBQX (Liu et al., 1997).

AMPA receptors normally assemble from four genetically distinct subunits: GluR1, GluR2, GluR3, and GluR4 (Keinanen et al., 1990), which combine to form receptor complexes with different functional properties (Hollmann et al., 1991; Hollmann and Heinemann, 1994). Cells expressing combinations of only GluR1, GluR3, and GluR4 form receptors (Jia et al., 1996) that are $\mathrm{Ca}^{2+}$ permeable, but incorporation of GluR2 eliminates this characteristic (Hollmann et al., 1991). Most AMPA receptors in the adult CNS are calcium impermeable because of nearly ubiquitous inclusion of the GluR2 subunit.

After ischemic brain injury, however, a specific reduction of the GluR2 subunit has been seen. This reduction after global (Pellegrini-Giampietro et al., 1992a) or forebrain (Heurteaux et al., 1994) ischemia precedes cell death and suggests that assembly of new, calcium-permeable AMPA receptors may contribute to neuronal loss (Gorter et al., 1997). Blocking the downregulation of GluR2 with aurintricarboxylic acid after brain ischemia prevents neurodegeneration (Aronica et al., 1998), further supporting this hypothesis.

The normal expression pattern of AMPA receptor subunits in the spinal cord has been studied by in situ hybridization (Furuyama et al., 1993; Tolle et al., 1993; Jakowec et al., 1995) and immunocytochemistry (Furuyama et al., 1993; Petralia et al., 1997). However, the effect of spinal cord trauma on the expression of the subunits and how these changes might relate to neuronal death after SCI (Crowe et al., 1997; Liu et al., 1997; Shuman et al., 1997) has not been studied. We used a standardized and well characterized rat contusion model (Wrathall et al., 1985) to examine GluR1, GluR2, GluR3, and GluR4 mRNA and protein levels acutely at $24 \mathrm{hr}$ and chronically at 1 month after SCI. 


\section{MATERIALS AND METHODS}

Spinal cord injury. SCI was performed as described previously (Wrathall et al., 1985). Female Sprague Dawley rats weighing 200-250 gm were used. Animals were housed on a $12 \mathrm{hr}$ light/dark cycle with standard rat chow and water ad libitum. Rats were anesthetized with chloral hydrate $(360 \mathrm{mg} / \mathrm{kg}$, i.p.), and a laminectomy was performed at $\mathrm{T} 8$, exposing a circle of dura. The spinal column was stabilized with angled Allis clamps on the T7 and T9 spinous processes, then the impounder tip of a weight drop device was lowered onto the dura. A $10 \mathrm{gm}$ weight was dropped from a height of $2.5 \mathrm{~cm}$ onto the impounder to produce spinal contusion. Controls for these experiments were age-, sex-, and weight-matched laminectomized rats. This model has been characterized in terms of biomechanics, resulting functional deficits, somatosensory evoked potentials, effects on the blood-spinal cord barrier, and quantitative histopathology (Gale et al., 1985; Noble and Wrathall, 1985, 1989; Panjabi and Wrathall, 1988; Raines et al., 1988). The incomplete contusion injury causes hindlimb paralysis and areflexia at $1 \mathrm{~d}$ followed by partial recovery of function that stabilizes to reveal the chronic functional deficits by 3 weeks after injury (Gale et al., 1985; Noble and Wrathall, 1989).

Post-surgical care. After the operation, rats were housed in pairs (to reduce stress from isolation) and kept at $22-25^{\circ} \mathrm{C}$ on highly absorbent bedding. Their bladders were manually expressed twice daily until a reflex bladder was established, usually at $\sim 9 \mathrm{~d}$ after injury.

Behavioral tests of functional deficits. All rats were tested blindly for functional deficits. Rats were analyzed with a battery of reflex tests that included toespread, placing, withdrawal in response to extension, pressure, pain, righting, and the reflex to lick their paws when placed on a hot surface (Gale et al., 1985). They were also tested for coordinated motor function including open-field locomotion, swimming, and ability to maintain position on an inclined plane. Laminectomy control rats were tested to ensure that there was no injury. Results in individual tests were examined separately, and in addition, overall hindlimb impairment was estimated with a combined behavioral score (CBS) that ranges from 0 in a normal rat to 100 in a rat with no hindlimb function (Gale et al., 1985). Furthermore, a more detailed examination of open-field locomotion was also performed using an expanded scale, known as the Basso, Beattie, Bresnahan (BBB) locomotor rating scale, that ranges from $0-21$, where 0 reflects no locomotory function and 21 reflects a normal performance (Basso et al., 1995).

Gel electrophoresis and immunoblotting. Animals were anesthetized with $4 \%$ chloral hydrate $(360 \mathrm{mg} / \mathrm{kg})$, and spinal cords were quickly removed. Samples of cord $(1.5 \mathrm{~cm})$ were taken from the thoracic level (including the epicenter of injury) as well as areas rostral (cervical enlargement) and caudal (lumbosacral enlargement). Tissue homogenates were prepared in TE buffer (10 mM Tris- $\mathrm{HCl}, \mathrm{pH} 7.4,1 \mathrm{~mm}$ EDTA). Protein concentrations were determined using BCA Assay Reagent (Pierce, Rockford, IL) to prepare samples with protein concentrations of $3 \mathrm{mg} / \mathrm{ml}$. Proteins were separated using SDS-PAGE containing 7.5\% polyacrylamide and transferred to polyvinylidene difluoride membranes (Towbin et al., 1979). The membranes were incubated in blocking buffer consisting of 5\% nonfat dry milk in TBST (20 mM Tris- $\mathrm{HCl}, \mathrm{pH}$ $7.4,140 \mathrm{~mm} \mathrm{NaCl}$, and $0.1 \%$ Tween-20) for $1 \mathrm{hr}$ at room temperature. They were then incubated in blocking buffer with affinity-purified antibodies, with antisera concentrations of $0.5 \mu \mathrm{g} / \mathrm{ml}$, directed against GluR1, GluR2/3, GluR4 (Chemicon, Temecula, CA), GluR2 (gift from Dr. Robert Wenthold, National Institutes of Health), or neuron-specific enolase (1:250 dilution NSE; Incstar, Stillwater, MN) overnight at $4^{\circ} \mathrm{C}$. After they were washed for $30 \mathrm{~min}$ with four intermediate changes with TBST, the membranes were incubated with horseradish peroxidaseconjugated donkey anti-rabbit antibody (Amersham, Arlington Heights, IL) at a dilution of 1:2000 for $1 \mathrm{hr}$ at room temperature in blocking buffer. After several washes with TBST, proteins were visualized with Super Signal reagents according to the manufacturer's instructions (Pierce, Rockford, IL) and apposed to Hyperfilm (Amersham). Films were placed in light-tight cassettes, exposed, developed, and air-dried.

Data analysis and quantification of immunoblots. Autoradiograms were analyzed and bands quantified by computer-assisted densitometry using a Bio Image Analysis System. This system calculates the integrated intensity of a band using both the density and the area of the band. In each experiment, a standard curve of known protein concentration from rat cortical tissue that had been fitted to a four-parameter logistic equation was constructed so that results could be quantified relative to the standard tissue.

The nonlinear regression fit to the standard curve data was performed using the following equation: $f(x)=a-d / 1+(x / c)^{b}+d$, with $a$ being the asymptotic maximum, $b$ being the slope parameter, $c$ being the value at the inflection point, and $d$ being the asymptotic minimum (Wang et al., 1995).

For a given experiment an aliquot of standard cortical tissue was thawed, and a series of twofold dilutions of known protein concentrations were prepared. The integrated intensities of the bands from experimental tissues determined at the same time and on the same piece of film were compared with the interpolated standard curve derived from the standards to yield a value of subunit expression relative to the standard cortical tissue. Thus, for example, a value of $2 \mu \mathrm{g}$ relative means that the experimental tissue expresses twice the amount of a given subunit than does rat cerebral cortex (Wang et al., 1995).

Histopathology and in situ hybridization. Spinal cords were rapidly removed from control and SCI rats, and $1.5 \mathrm{~cm}$ segments of cervical, thoracic, and lumbar cord were embedded in OCT (Tissue-Tek). Spinal cords segments from the same cord region were embedded as sets consisting of one or two injured segments and one uninjured control segment that were sectioned together at $20 \mu \mathrm{m}$ on a Jung Frigocut 2800 E cryostat. Slides thus contained sections of control and experimental tissues that were processed together. Sections were thaw-mounted onto RNase-free, 3-aminopropyltriethoxysilane (Sigma, St. Louis, MO)coated slides such that each slide represented $100 \mu \mathrm{m}$ of tissue and then stored at $-20^{\circ} \mathrm{C}$

Slides representing every millimeter length of cord were stained with luxol blue and counterstained with hematoxylin and eosin and used to reconstruct the injury site, as described previously (Noble and Wrathall, 1989; Teng and Wrathall, 1997). Based on this, a series of slides representing the lesion epicenter and specified distances rostral and caudal to it (see Fig. 1C) were selected for hybridization with various probes.

${ }^{35} \mathrm{~S}$-dATP-labeled antisense oligonucleotide probes had the following sequences (Keinanen et al., 1990) that recognize flip and flop splice variants (Sommer et al., 1990). The sequences used were as follows: GluR1, GTC ATC GGT TGT CTG GTC TCG TCC CTC TTC AAA CTC TTC GCT GTG AA; GluR2, TTC ACT ACT TTG TGT TTC TCT TCC ATC TTC AAA TTC CTC AGT GTG; GluR3, AGG GCT TTG TGG GTC ACG AGG TTC TTC ATT GTT GTC TTC CAA GTG; and GluR4, CTG GTC ACT GGG TCC TTC CTT CCC ATC CTC AGG TTC TTC TGT GTG.

Oligonucleotides were $3^{\prime}$ end-labeled by combining $3.0 \mu \mathrm{l} 5 \times$ tailing buffer, $5.0 \mu \mathrm{l}$ of a solution containing $25 \mathrm{mM} \mathrm{CoCl}_{2}, 0.5 \mu \mathrm{l} 10 \mathrm{pmol} / \mu \mathrm{l}$ oligonucleotide, $5.0 \mu \mathrm{l}\left[{ }^{35} \mathrm{~S}\right] \mathrm{dATP}$, and $1.5 \mu \mathrm{l} 25 \mathrm{U} / \mu \mathrm{l}$ terminal transferase (all chemicals and buffers from Boehringer Mannheim, Indianapolis, IN) in a microcentrifuge tube on wet ice and incubated at $37^{\circ} \mathrm{C}$ for $7 \mathrm{~min}$. Three hundred microliters of TE (10 mM Tris, $1 \mathrm{~mm}$ EDTA, $\mathrm{pH}$ $8)$, then $2 \mu \mathrm{l}$ of yeast tRNA $(25 \mathrm{mg} / \mathrm{ml})$ were added; $300 \mu \mathrm{l}$ of phenol/ chloroform/isoamyl alcohol (P-3803, Sigma, St. Louis, MO) were added, and the tube was vortexed and microcentrifuged at $14,000 \mathrm{rpm}$ for 10 min. The aqueous phase was transferred to a new tube and $30 \mu \mathrm{l}$ of $3 \mathrm{M}$ $\mathrm{NaAc}, \mathrm{pH} 5.2$, and then $340 \mu \mathrm{l}$ of isopropanol were added. The tube was vortexed, and the mixture was microcentrifuged for $30 \mathrm{~min}$ at 14,000 rpm. The pellet was rinsed with $800 \mu \mathrm{l}$ of $80 \% \mathrm{EtOH}$ and air-dried by inverting the tube for 5-10 min. Finally, the pellet was dissolved in $100 \mu \mathrm{l} \mathrm{TE,} \mathrm{pH} \mathrm{8.0,}$ with $1 \mu \mathrm{l}$ of $5 \mathrm{M}$ dithiothreitol (DTT) to yield labeled probes with specific activities that ranged from $480,000 \mathrm{cpm} / \mu \mathrm{l}$ to $1,000,000 \mathrm{cpm} / \mu \mathrm{l}$.

For in situ hybridization, tissue sections were first post-fixed in $4 \%$ paraformaldehyde in $1 \times$ PBS for $5 \mathrm{~min}$. Slides were then acetylated in $0.25 \%$ acetic anhydride in $0.1 \mathrm{~m}$ triethanolamine, $\mathrm{pH} 8.0$, for $10 \mathrm{~min}$ followed by dehydration through a graded ethanol/chloroform series. Hybridization buffer was prepared $[2 \mathrm{ml} 20 \times$ standard sodium citrate (SSC), $0.2 \mathrm{ml}$ diethylpyrocarbonate-treated $\mathrm{H}_{2} \mathrm{O}, 5 \mathrm{ml} 100 \%$ formamide, $0.2 \mathrm{ml} 50 \times$ Denhardt's solution, $0.1 \mathrm{ml} 25 \mathrm{mg} / \mathrm{ml}$ yeast tRNA, $0.5 \mathrm{mg} / \mathrm{ml}$ salmon sperm DNA, $2 \mathrm{ml} 50 \%$ dextran sulfate $500 \mathrm{~K}$ ). Hybridization buffer was combined with $1 / 50$ volume of $5 \mathrm{M}$ DTT and an appropriate amount of probe [(no. of slides +1$) *\left(1 \times 10^{6} \mathrm{cpm}\right) /(\mathrm{cpm} / \mu \mathrm{l}$ of probe $\left.)\right]$. By preparing hybridization solution this way, we normalize for differences in probe-specific activity. Solution was placed on each slide (100 $\mu \mathrm{l})$, coverslipped, and incubated $\left(37-40^{\circ} \mathrm{C}\right.$ for $\left.20-24 \mathrm{hr}\right)$ in a Petri dish lined with wet filter paper. Dipping in three different $1 \times$ SSC solutions of $200 \mathrm{ml}$ each soaked off the coverslips. Slides were washed three times for 20 min each time in $2 \times \mathrm{SSC}$ containing $50 \%$ formamide at $40.5^{\circ} \mathrm{C}$, then twice for $30 \mathrm{~min}$ each in $1 \times \mathrm{SSC}$ at room temperature. Finally, slides were rinsed twice in $\mathrm{dH}_{2} \mathrm{O}$, then for $1 \mathrm{~min}$ in $70 \% \mathrm{EtOH}$. Slides were air-dried and dipped in Kodak NT2B emulsion (Rochester, NY), sealed in light-tight boxes, and kept at $4^{\circ} \mathrm{C}$.

After 7 weeks, slides were developed with D19 developer, fixed with general-purpose fixer (Kodak), and counterstained with neutral red for 
visualization of cell bodies. Grain counting was performed using a computerized image analysis system (Image Pro Plus, Media Cybernetics, Silver Spring, MD) with a program specifically designed to count grains after in situ hybridization. The program identified cell bodies by detecting the neutral red stain, quantified the area of the cell body (square micrometer), and counted the grains overlying it. These values were used to calculate the average density of grains (grains/square micrometer) for a given cell. All values were corrected for background by sampling adjacent areas of the slide without tissue $(n=5)$ and subtracting the density of grains in the background from the density of grains in experimental samples. Most of the data we report are from sections \pm 4 $\mathrm{mm}$ from the injury epicenter, where motor neurons look healthy, as determined by their nuclear morphology and the presence of Nissl substance, unless specified otherwise.

For the analysis at $\pm 4 \mathrm{~mm}$, a total of 93-141 individual thoracic neurons were counted per rat. Initially and for each rat, the grains/square micrometer overlying ventral motor neurons (VMNs) at $4 \mathrm{~mm}$ rostral to the T8 epicenter were found to be similar (by Student's $t$ test) to the equivalent neurons at $4 \mathrm{~mm}$ caudal. This was the case for autonomic preganglionic neurons of the intermedial lateral horn (IML) as well. Next, the grains/square micrometer overlying VMNs and IML neurons at $+4 \mathrm{~mm}$ and $-4 \mathrm{~mm}$ were compared for the SCI and uninjured control sections mounted on the same slides. SCI neurons were significantly different from control at both rostral and caudal positions, or both were nonsignificant. In addition, there were no significant differences in grain density per neuron from laminectomy control rats killed at $24 \mathrm{hr}$ compared with those killed at $28 \mathrm{~d}$ after surgery; thus the two control groups were combined. Therefore, the $\pm 4 \mathrm{~mm}$ data for each rat was combined for the final analyses, which were based on the average grains/square micrometer overlying VMNs (or IML neurons) in each rat, with $n=5$ acute SCI rats, $n=5$ chronic SCI rats, compared with $n=7$ laminectomy controls. For lumbar analysis, 37-49 individual neurons were counted, using the same analysis as that used for thoracic neurons.

Grain counts for VMNs were also made in sections at $\pm 2, \pm 6, \pm 8$, -15 , and $-20 \mathrm{~mm}$ from the epicenter. In these cases the average VMN grain density at each level in each rat was determined based on counts of 13 (in $\pm 2 \mathrm{~mm}$ sections) to 24 neurons. The average grain density was compared for the neurons in SCI and laminectomy control tissue on the same slides ( $n=5$ rats per group).

Statistical analysis. To determine significance, all data were subjected to statistical analysis using a computerized statistics program (Sigmastat SPSS, San Raphael, CA). ANOVA or repeat-measures ANOVA was used, as indicated in the figure legends, followed by a post hoc test (Tukey) of differences between specific groups or time points. A level of $p<0.05$ was considered significant.

\section{RESULTS}

\section{Production of reproducible injuries and determination of the injury epicenter}

Behavior was assessed at $24 \mathrm{hr}$ after injury for all animals $(n=56)$ and weekly thereafter in animals allowed to survive for 1 month $(n=14 \mathrm{SCI}$ and 14 controls) (Fig. 1A,B). As expected, laminectomy controls showed no signs of functional deficit at any time examined based on either the CBS or BBB scores (see Materials and Methods for details), the two motor rating scales used (Fig. $1 A, B)$. Acute SCI rats had severe functional impairments $24 \mathrm{hr}$ after SCI, consistent with what we have reported previously (Teng and Wrathall, 1997; Wrathall et al., 1997). This was reflected in BBB scores of 0 and CBS scores ranging from 95 to 100, indicating serious deficiencies in hindlimb performance. Although never reaching control levels, hindlimb function partially recovered by 1 month to average a BBB of $12 \pm 0.6(\mathrm{SD})$ and a CBS of $44 \pm 3.2$ (Fig. 1A,B).

Histological assessment of tissue was used to identify the injury epicenter and visualize the extent of injury based on tissue loss. As expected, a cavity formed because of tissue loss in the thoracic spinal cord of all chronically injured rats. This is seen in a tracing of a typical epicenter (region of maximal tissue loss), shown in Figure $1 C$, along with tracings of sections at 1 and $4 \mathrm{~mm}$ rostral $(+)$ and caudal $(-)$ to the epicenter. All of the chronic injury sites
A. CBS Score

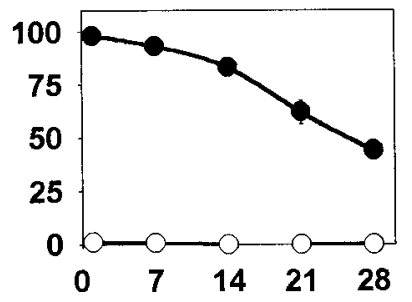

B. BBB Score

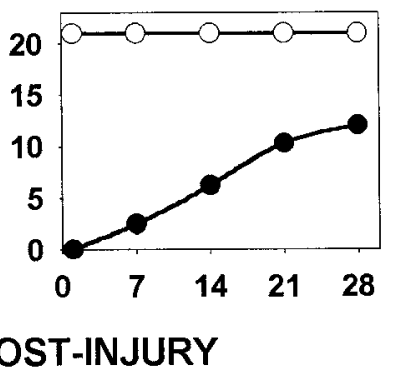

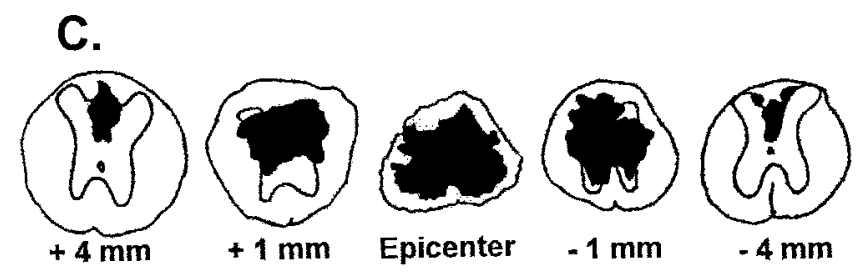

Figure 1. Outcome of the experimental weight-drop model of contusive spinal cord injury used in the study. $A$, Results of behavioral testing of rats using the combined behavioral score (CBS Score) (Noble and Wrathall, 1985), a measure of overall hindlimb deficit. $B$, Results using the Basso, Beattie, Bresnahan scale (BBB Score) (Basso et al., 1995) of hindlimb locomotor ability (see Materials and Methods for full description). Both measures of hindlimb function demonstrate profound deficit at $24 \mathrm{hr}$ and partial recovery with a residual chronic deficit at 1 month. Data points indicate mean \pm SD for the groups of rats $(n=28$ each $)$ after T8 laminectomy $(\bigcirc-\bigcirc)$ or laminectomy plus SCI rats $(-0)$ produced with a weight-drop device $(10 \mathrm{gm} \times 2.5 \mathrm{~cm})$. Because of the reproducibility of the injury model, the SD bars are generally hidden by the symbols. $C$, Tracings of a representative injured spinal cord at 1 month after injury showing the epicenter (region of maximal damage) and sections 1 and 4 $\mathrm{mm}$ rostral and caudal to it. Black region indicates the lesion area, which consists of cavities and a loose accumulation of lesion cells, primarily macrophages (Noble and Wrathall, 1985, 1989; Wrathall et al., 1998).

demonstrated a similar pattern of injury with lesions tapering rostrocaudally, so that tissue sections at $\pm 4 \mathrm{~mm}$ from the epicenter show only small areas of cavitation. We therefore chose sections at $\pm 4 \mathrm{~mm}$ for the primary quantitative analysis of grains over VMNs and IML neurons after in situ hybridization.

\section{Normal expression of AMPA receptor subunit proteins in adult rat spinal cord}

Western blot analysis was used to assess protein levels of AMPA receptor subunits in our two control groups: uninjured rat spinal cords at $24 \mathrm{hr}$ and at 1 month after laminectomy (Fig. $2 A$ ). Using antibodies against GluR1, GluR2, GluR2/3, and GluR4, each of the AMPA subunits was detectable in the cervical, thoracic, and lumbar samples from spinal cords in the laminectomy control group. Because there were no statistically significant differences at a particular spinal level (e.g., cervical) between the $24 \mathrm{hr}$ and 1 month control groups for any of the subunits, the data from the two sets of controls were combined (total $n=17$ ).

The anti-GluR1 antibody detected protein in all three levels examined: the cervical enlargement, the thoracic region, and the lumbosacral enlargement (Fig. 2A,B). Levels of GluR1 did not vary according to region and appeared to be uniform and detectable along the length of the cord. On the other hand, GluR2 protein, measured using a polyclonal GluR2 antibody, was significantly higher in the lumbar than in the thoracic or cervical cord. There were no differences in GluR2 levels in the cervical and thoracic cord (Fig. 2B). Because a GluR3-specific antibody was 

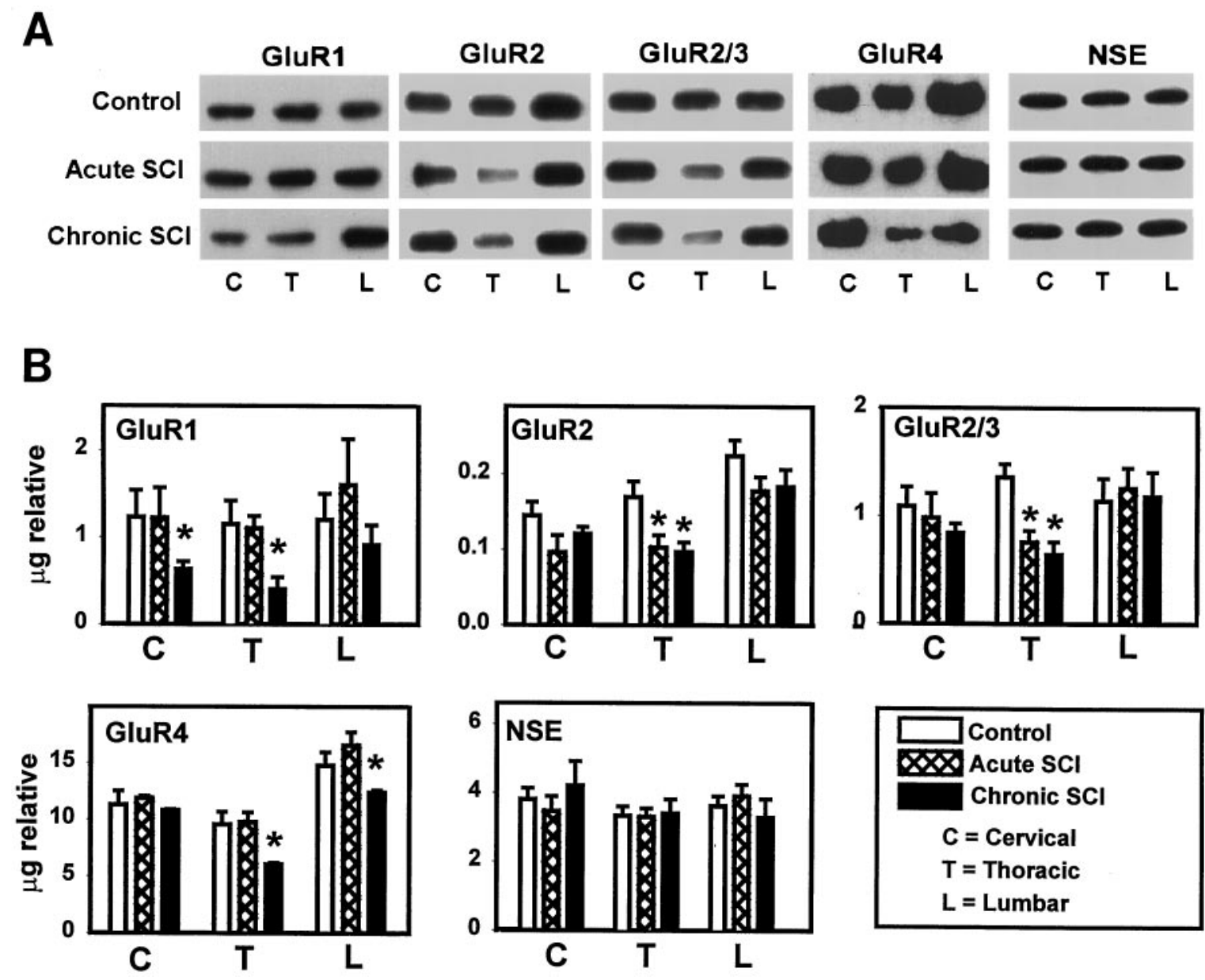

Figure 2. Levels of AMPA receptor subunit proteins are altered at $24 \mathrm{hr}$ and 1 month after SCI, as measured by quantitative analysis of Western blots. $A$, Typical Western blots using polyclonal antibodies directed against AMPA receptor subunits are shown. The top blot on each column represents control protein levels, the middle blot represents acute SCI levels at $24 \mathrm{hr}$ after injury, and the bottom blot represents levels at 1 month after SCI for GluR1, GluR2, GluR2/3, GluR4, and NSE. C, Cervical; $T$, thoracic; $L$, lumbar. B, Relative protein levels were quantified for each subunit as described in Materials and Methods for GluR1, GluR2, GluR2/3, GluR4, and NSE. For all graphs, white bar $=$ control levels $(n=16-18$ rats), cross-hatched bar $=$ $24 \mathrm{hr}$ after SCI $(n=8)$, black bar $=1$ month after SCI $(n=9)$. Repeat-measures ANOVA was used to compare all nine experimental groups for each antibody with post hoc comparisons by the Tukey test. *Significantly different from level in laminectomy controls, $p \leq 0.05$.

not available at the time of these experiments, a GluR2/3 polyclonal antibody that recognizes the common C terminus of GluR2 and GluR3 was used. Results were similar to that seen for GluR1 in that normal GluR2/3 protein expression was uniform along the length of the spinal cord (Fig. $2 B$ ). The antibody directed against GluR4 protein showed a slight but not significant $(p=0.053)$ elevated expression in lumbar cord (Fig. 2B). As a control, we also assessed levels of neuron-specific enolase (NSE). This was done to ensure that there were no significant differences in the number of metabolically active neurons relative to sample protein in each area of the uninjured spinal cord. We found no significant differences in NSE protein levels (micrograms of relative NSE per $3 \mu \mathrm{g}$ homogenate protein) in the samples of cervical, thoracic, and lumbar cord (Fig. 2B).

\section{Acute changes in AMPA receptor subunit protein levels after contusive SCI}

Each of the subunits investigated was still readily detectable $24 \mathrm{hr}$ after SCI, as revealed by quantitative Western blot (Fig. 2A,B). The anti-GluR1 antibody showed that GluR1 protein did not change acutely after SCI. At $24 \mathrm{hr}$ after injury, levels of GluR1 protein in cervical, thoracic, or lumbosacral areas of the cord were equal to control levels in tissue from uninjured rats (Fig. $2 B$ ). On the contrary, GluR2 protein was reduced by $40 \%$ in the epicenter area by $24 \mathrm{hr}$ after injury, as revealed by use of a specific polyclonal antibody against GluR2 (Fig. 2B). Furthermore, a significant $39 \%$ decrease in GluR2/3 protein levels in the thoracic epicenter was seen by $24 \mathrm{hr}$ after injury (Fig. $2 \mathrm{~B}$ ). These blots were probed with a GluR2/3 antibody, which recognizes the $C$ termini of both GluR2 and GluR3 subunits. Although changes in GluR2 and GluR2/3 could be seen in the thoracic area of the cord, no significant changes in cervical or lumbar regions were seen at this acute time point. As with GluR1, GluR4 levels at 24 hr after injury remained similar to uninjured controls (Fig. 2B). In addition, NSE levels were not altered in the acutely injured tissue samples (Fig. 2B).

\section{Chronic changes in AMPA receptor subunit protein levels after contusive SCI}

We also evaluated AMPA subunit protein levels at 1 month after SCI (Fig. $2 A, B$ ). We found that GluR1 protein was significantly decreased by $73 \%$ in the thoracic cord at 1 month after injury (Fig. $2 B$ ). In addition to thoracic changes, GluR1 protein levels were significantly decreased by $44 \%$ in the cervical cord samples. 


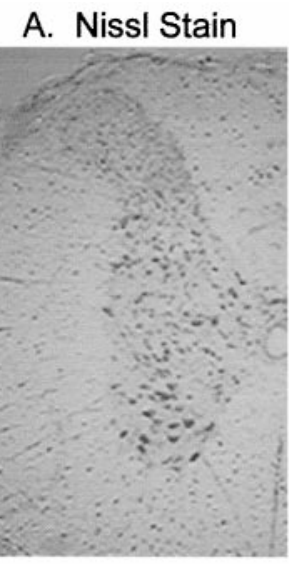

E. Regions

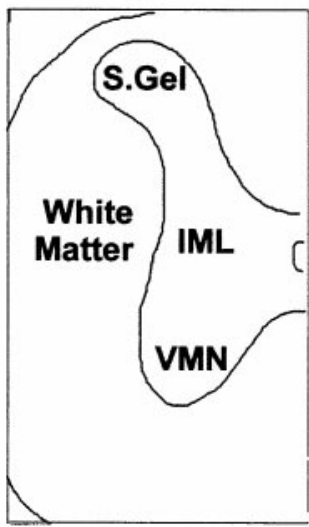

B. GluR1

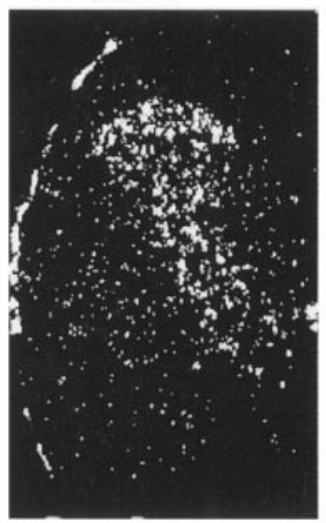

F. GluR2

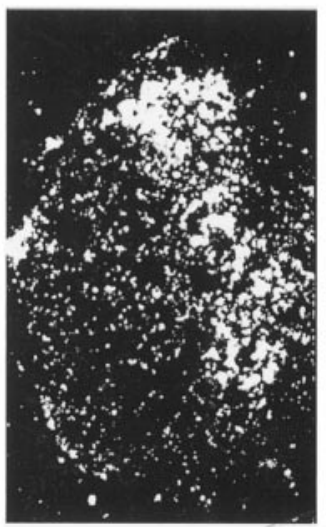

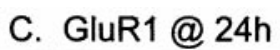

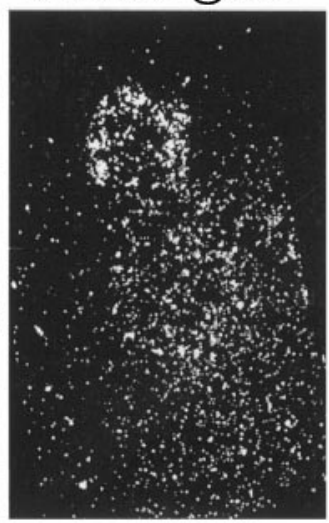

G. GluR2 @ 24h

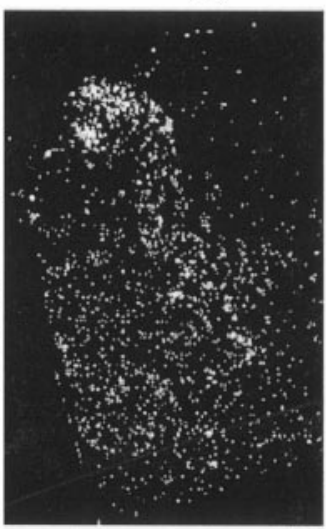

\section{GluR3}

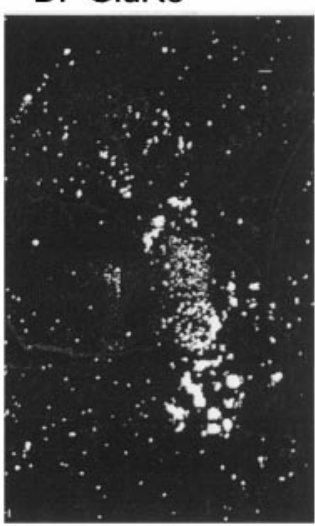

H. GluR4

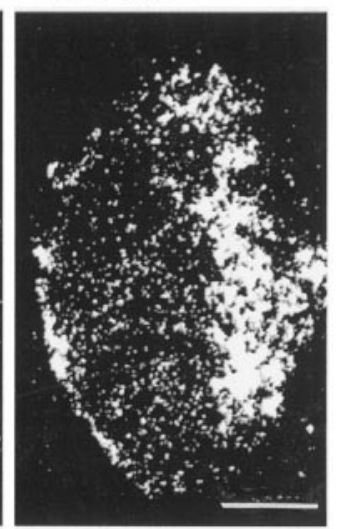

Figure 3. Dark-field microscopy showing autoradiographic grains overlying areas of mRNA expression in thoracic spinal cord hemisections from laminectomy control and acute SCI rats. $A$, Nissl-stained hemisection of normal spinal cord. $B$, Normal expression of GluR1 mRNA. $C$, Reduced GluR1 mRNA expression in a section $2 \mathrm{~mm}$ caudal to the epicenter $24 \mathrm{hr}$ after SCI. D, Normal expression of GluR3 mRNA. E, Tracing of normal spinal cord showing regions examined in this study. $F$, Normal expression of GluR2 mRNA. $G$, Decreased expression of GluR2 mRNA 2 mm caudal to the epicenter $24 \mathrm{hr}$ after SCI. H, Normal expression of GluR4 mRNA. Exposure times and the specific activities of the probes were similar for all sections. Scale bar, $0.5 \mathrm{~mm}$

However, no significant reduction of GluR1 was seen in the lumbar cord. GluR2 protein displayed a trend toward downregulation in all three areas of the cord at 1 month (Fig. 2A,B). Despite this, only the $41 \%$ decrease at the thoracic level was significant. The GluR2/3 antibody revealed a persistent $47 \%$ decrease in GluR2/3 protein at the thoracic area (Fig. $2 B$ ). As in acute SCI, neither the cervical enlargement nor the lumbar region showed a change in GluR2/3 protein chronically. GluR4, in contrast to its acute profile, which remained unchanged, was chronically decreased in both the thoracic and lumbar regions of the cord, whereas cervical levels remained equal to control at 1 month after injury (Fig. $2 B$ ). NSE levels were not changed in the chronically injured spinal cords (Fig. $2 A, B$ ).

\section{Normal AMPA receptor subunit mRNA expression in adult rat spinal cord}

In situ hybridization was used to investigate changes in mRNA in specific neuronal populations. Use of each probe resulted in distinct patterns of labeling in the normal thoracic spinal cord, as viewed by dark-field microscopy (Fig. 3B,D,F,H). The GluR1 oligoprobe intensely labeled cells in the superficial lamina of the dorsal gray matter of the spinal cord, with very low to undetectable levels in the ventral horn (Fig. 3B). GluR2 was highly expressed in the substantia gelatinosa and other superficial lam- inae of the dorsal horn. It was also moderately detectable in cells throughout the gray matter, with light labeling in motor neurons of the ventral horn (Fig. $3 F$ ). GluR3 did not label cells in the dorsal gray matter (Fig. $3 D$ ), but labeling was pronounced in the ventral horn, with moderate to strong labeling of the ventral motor neurons. GluR4 was detectable in the substantia gelatinosa and strongly labeled ventral motor neurons in the gray matter (Fig. 3H). In addition, white matter labeling for GluR2 and GluR4 was above background. Labeling patterns were similar for cervical and lumbar cord regions (data not shown).

\section{Acute changes in AMPA receptor subunit mRNA after $\mathbf{S C I}$}

Acutely injured spinal cord tissue was also examined for subunit mRNA using dark-field microscopy to determine overall silver grain distribution. By $24 \mathrm{hr}$, tissue was visably injured. The center of the spinal cord at the T8 injury epicenter was essentially devoid of neurons and replaced with a lesion (Fig. $1 C$ ), making it impossible to determine grain distribution and compare it with controls. In these sections, there was mechanical damage and widespread cell loss, and the pattern of GluR1-4 staining seen in controls was abolished. The relative intensity of grains was equal to background and uniform over the entire spinal cord section. At distances of $\pm 2 \mathrm{~mm}$ from the epicenter, the normal pattern of grains 
began to reappear faintly (Fig. 3C,G), but histological evaluation of adjacent sections indicated that many VMNs and IML neurons had been lost. Thus, we examined tissue $4 \mathrm{~mm}$ distal to the epicenter, where the pattern of grain distribution was maintained and the spinal tissue was largely intact, although clearly altered by the injury (Fig. 1C). Light microscopy at $400 \times$ magnification was used to count individual autoradiographic grains.

\section{Quantitative analysis of AMPA receptor subunit mRNA expression after $\mathrm{SCl}$ in specific neuronal populations}

To determine how SCI affects AMPA subunit expression in specific cell types, two cholinergic populations of motor neurons that express AMPA receptors were compared. We counted grains over large (diameter $\geq 14 \mu \mathrm{m}$ ) motor neurons of the VMN and sympathetic preganglionic neurons of the IML. The characteristic large cell bodies of the former and their presence in the ventral horn as well as a comparison with similar slides stained with choline acetyltransferase identified VMNs (Teng et al., 1998). IML neurons were identified by comparison of in situ hybridized slides with similar slides stained for choline acetyltransferase, which labeled a small population of $\sim 8-10$ cholinergic IML neurons per horn in the peripheral rim of intermediolateral gray matter.

Autonomic IML neurons decreased GluR1 mRNA acutely after injury from $9.7 \pm 0.9$ grains (expressed as mean $\pm \mathrm{SE}$ ) $/ \mu \mathrm{m}^{2}$ of cell in control sections to $4.6 \pm 0.6$ grains in sections of IML neurons from injured rats (see Fig. $5 A$ ). On the other hand, levels of AMPA receptor subunit mRNA encoding GluR2 and GluR3 were indistinguishable from control levels (see Fig. $5 A$ ) in this cell population (GluR2, $5.9 \pm 0.7$ in controls vs $7.8 \pm 1.6$ in SCI; GluR3, $5.9 \pm 0.6$ vs $6.5 \pm 0.4)$. GluR4 mRNA was barely detectable in the IML neurons and was unchanged after SCI; $2.1 \pm 0.1$ versus $2.3 \pm 0.2$ grains $/ \mu \mathrm{m}^{2}$. The low levels of GluR4 mRNA we found are consistent with previously published data that GluR4 protein is not detected in IML neurons by immunochemistry (McNair et al., 1998).

VMNs were also analyzed by in situ hybridization (Figs. 4, 5). Quantification of results (Fig. 5B) demonstrated that GluR1 was barely detectable in this cell population, with grains being only slightly above background in some neurons and not significantly changed at $24 \mathrm{hr}$ after injury $(0.8 \pm 0.1$ vs $1.3 \pm 0.3)$. However, GluR2 mRNA showed a significant decrease of $37 \%$ at $24 \mathrm{hr}$ after injury in ventral horn motor neurons from $5.2 \pm 0.3$ grains $/ \mu \mathrm{m}^{2}$ in normal controls to $3.3 \pm 0.3$ grains $/ \mu \mathrm{m}^{2}$ acutely after SCI (Fig. $5 B)$. GluR4 mRNA was also significantly decreased in VMNs by $\sim 20 \%$. The average number of grains for the controls was $32.6 \pm$ 1.7, whereas their corresponding injured counterparts had mean grain counts of $26.5 \pm 1.4$. GluR3 expression in VMNs did not change after SCI $(9.9 \pm 0.8$ in controls vs $10.2 \pm 1.2$ after SCI).

In addition to thoracic changes, we also examined the lumbar cord at this time. At $24 \mathrm{hr}$ after injury, the lumbar cord VMNs were unchanged compared with controls with respect to mRNA encoding GluR1-4 (data not shown). IML neurons could not be examined because preganglionic neurons are not present at this level of the cord. Thus, at $24 \mathrm{hr}$ after SCI, no alterations in AMPA receptor subunit mRNA were detected distally.

\section{Chronic cellular changes in AMPA receptor subunit mRNA levels after SCI}

The number of grains overlying VMNs and IML neurons in chronically injured cords at $4 \mathrm{~mm}$ rostral were compared with equivalent neurons at $4 \mathrm{~mm}$ caudal to the T8 epicenter by Student's $t$ test and found to be similar to each other. Therefore, the $\pm 4 \mathrm{~mm}$ data were combined.
At 1 month after injury, thoracic IML neurons continued to exhibit decreased GluR1 mRNA without changes in levels of any other subunits (Fig. 5C). VMNs were also examined at 1 month after SCI (Fig. 5D). The downregulation of GluR2 in VMNs at $24 \mathrm{hr}$ persisted at 1 month (Figs. $4 A, B, 5 B, D$ ). Control VMNs had $4.6 \pm 0.5$ grains $/ \mu \mathrm{m}^{2}$ versus $3.2 \pm 0.4$ grains $/ \mu \mathrm{m}^{2}$ in chronically injured motor neurons. This $30 \%$ decrease is consistent with GluR2 protein levels at this time point (Fig. 2B). The acute decrease in GluR4 mRNA was also maintained in the chronic animals (Fig. 4C,D). No change in either GluR1 (Fig. 4E,F) or GluR3 (Fig. 4G,H) mRNA in thoracic motor neurons was observed at 1 month after injury.

At this chronic time point, surviving lumbar neurons distal to the injury site displayed a significant $20 \%$ decrease in GluR2 mRNA. This is in contrast to the data at $24 \mathrm{hr}$ after injury, which showed no effects of SCI on any AMPA subunit mRNA in neurons in the lumbar cord. Considering these data, we further analyzed GluR2 mRNA levels in VMNs along the length of the spinal cord at 1 month after SCI (Fig. 6). Results show that GluR2 is downregulated in motor neurons along the length of the cord, with the greatest effect closer to the injury site.

\section{DISCUSSION}

We have studied changes in AMPA receptor subunit expression consequent to contusive spinal cord injury. The expression patterns of the AMPA receptor subunits we observed in the spinal cords of uninjured controls were consistent with published findings (Furuyama et al., 1993; Tolle et al., 1993; Tachibana et al., 1994). Each subunit had a distinct profile in the spinal cord and was still detectable in preserved tissue after injury, although there were significant changes in expression levels. In situ hybridization indicated that the decrease in GluR2 protein seen by Western analyses was associated with decreased GluR2 mRNA in the dorsal horns and in VMNs but not in autonomic preganglionic IML neurons. At $\pm 4 \mathrm{~mm}$ from the epicenter where we performed quantitative analyses, IML neurons did not show any change in expression of GluR2 mRNA relative to uninjured controls. However, GluR1 was significantly decreased in these neurons. In contrast, VMNs showed not only a marked reduction in GluR2 mRNA but also a lesser, but still significant, acute reduction in GluR4 mRNA. The GluR1 and GluR3 mRNA levels in VMNs were indistinguishable from normal controls at $24 \mathrm{hr}$ after SCI. The simplest interpretation of our data is that SCI leads to the formation of AMPA receptors with altered subunit compositions and the induced alterations are population-specific, at least regarding IML neurons and VMNs. However, immunoprecipitation studies (Wenthold et al., 1992, 1996; Luo et al., 1997) are required to determine whether altered subunit expression is reflected in altered composition of assembled receptors after SCI.

A potential problem associated with counting grains in this study is that neutral red stains only the cell body, leaving dendrites and axons unidentifiable. Thus, an alternative interpretation of our results would be that injury induces changes in mRNA distribution (soma vs neurites) rather than an overall change in mRNA per cell; however, this is unlikely. AMPA subunit mRNA is localized in neuronal somata in normal spinal cord (Tomiyama et al., 1996). We found a similar distribution after SCI, with few grains not associated with Nissl-stained cell bodies (Fig. 4).

Chronically, Western analyses showed that GluR1, GluR2, and GluR4 proteins are all significantly decreased in the thoracic spinal cord near the injury site. Because no antibody recognizes 

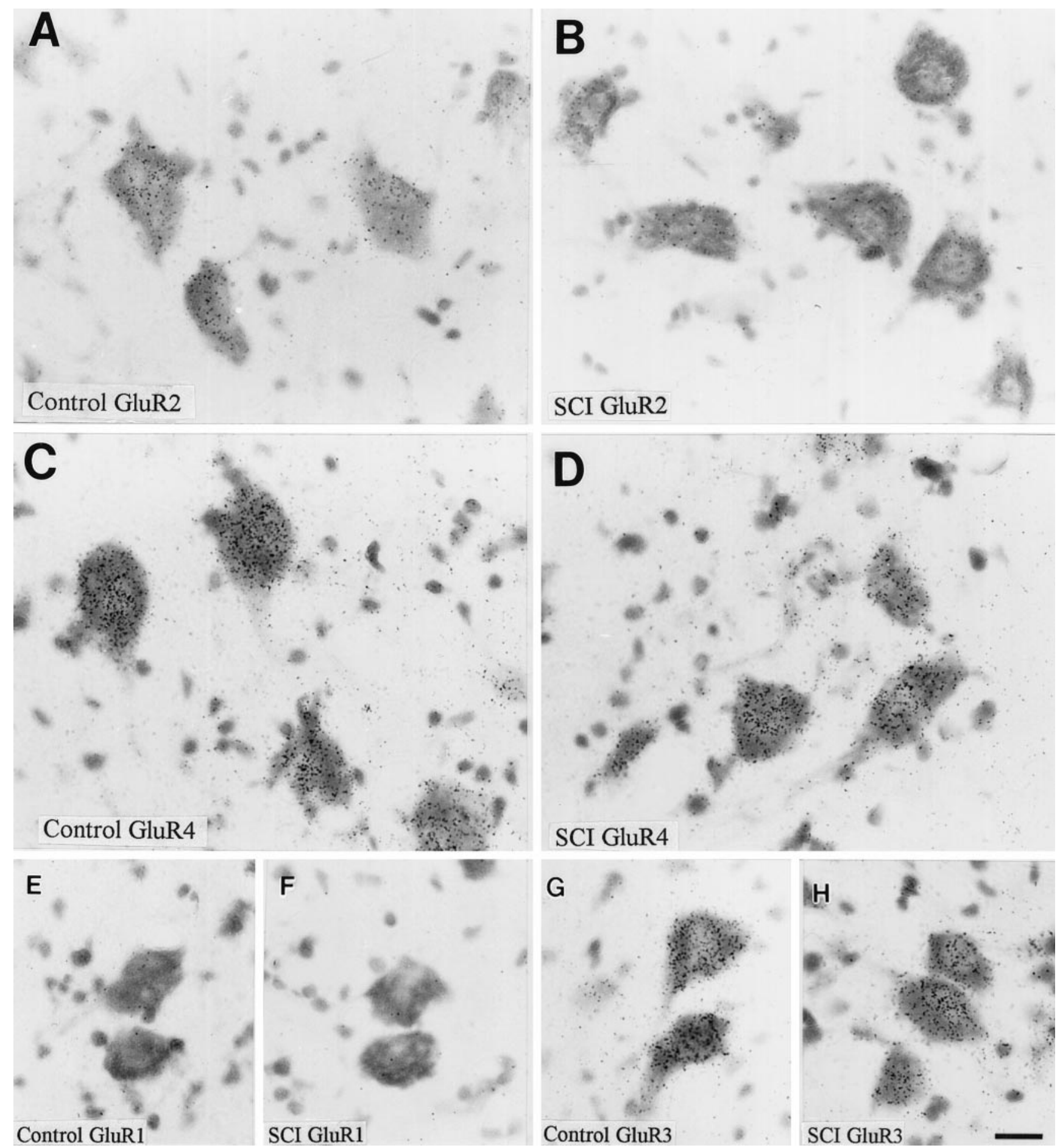

Figure 4. Expression of AMPA subunit GluR2 mRNA is specifically altered in ventral motor neurons 1 month after SCI. Bright-field photomicrographs showing healthy appearing, Nissl-stained, ventral motor neurons. VMNs are located $4 \mathrm{~mm}$ caudal to the thoracic epicenter in controls and SCI rats, at 1 month after laminectomy or weight-drop injury. $A$, GluR2 mRNA in VMNs of control rats is moderately expressed. $B$, Decreased GluR2 mRNA in VMNs from injured rats. $C$, GluR4 mRNA expression is high in control VMNs. $D$, VMNs from SCI rats express slightly but significantly less GluR4 mRNA than controls. $E$, GluR1 mRNA is sparse in VMNs from control spinal cord. $F$, VMNs from SCI rats express similar levels of GluR1 mRNA as controls. $G$, GluR3 mRNA expression is high in control spinal cord and is similarly high 1 month after injury $(H)$. Scale bar $=5 \mu$ m.

GluR3 alone, specific information on this protein was unattainable. However, the decrease seen with GluR2/3 antibody may indicate a downregulation of GluR3. Importantly, NSE protein is not decreased, suggesting that reduced subunit protein levels are not simply caused by neuronal loss. Thus, all AMPA subunits may be downregulated chronically. An intriguing possibility would be an altered ratio of NMDA to non-NMDA receptors chronically after SCI. Preliminary studies support this hypothesis because protein levels of the NMDA NR1 subunit, an obligatory member of all functional NMDA receptors (Monyer et al., 1992), do not 
A

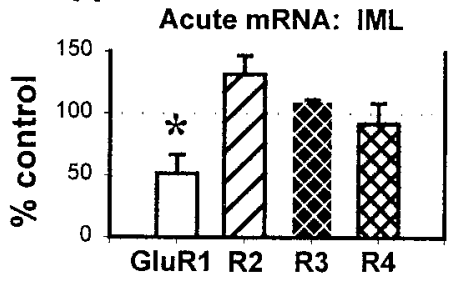

B

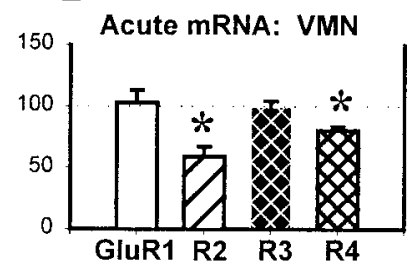

C

Chronic mRNA: IML

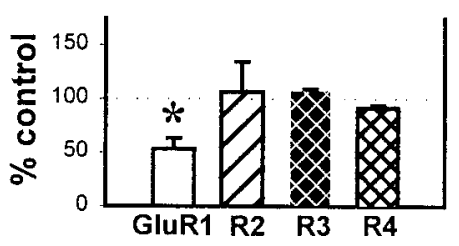

D

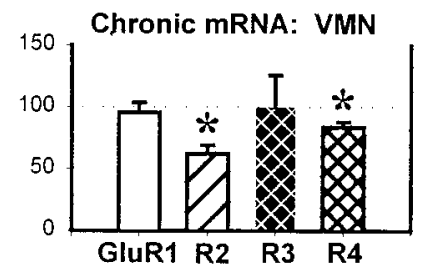

Figure 5. Different populations of neurons exhibit distinct alterations in AMPA receptor subunit mRNA expression after SCI. Graphs represent grain density overlying individual ventral motor neurons $(V M N)$ or IML neurons expressed as a percentage of grain counts from adjacent laminectomy control sections on the same slide. Sections analyzed were from $4 \mathrm{~mm}$ rostral and caudal to the epicenter of injury, where for the most part tissue was morphologically intact. $A$, IML neurons at $24 \mathrm{hr}$ after SCI. $B$, Ventral motor neurons at $24 \mathrm{hr}$ after SCI. $C$, IML neurons at 1 month after SCI. $D$, Ventral motor neurons at 1 month after SCI. $n=5$ rats per group with 93-141 VMNs and IML neurons analyzed per animal. *Significant difference between grains per square micrometer of neuron in control and SCI groups (Student's $t$ test, $p \leq 0.05$ ).

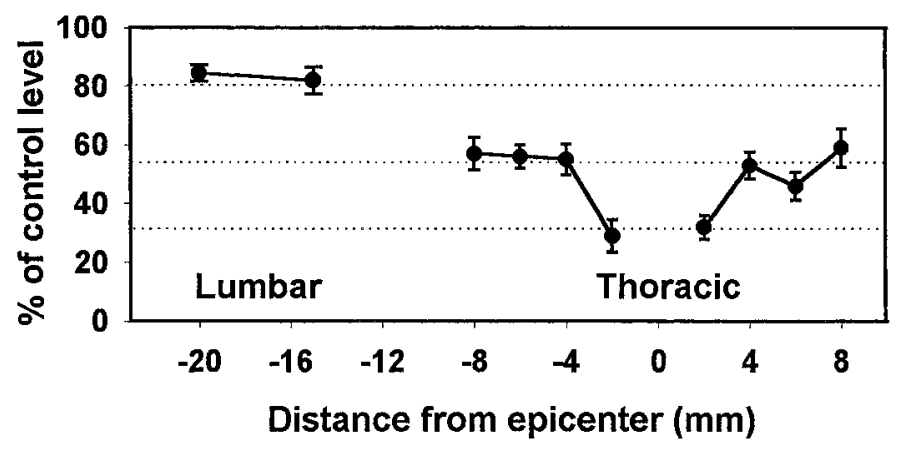

Figure 6. Quantitative analysis shows that GluR2 mRNA is chronically downregulated in ventral motor neurons adjacent to the injury site and also distally in the lumbar enlargement. Graph represents grain counts as a percentage of control ( $y$-axis) for individual ventral motor neurons at various millimeter distance increments rostral and caudal to the injury epicenter ( $x$-axis). There is a significant decrease in GluR2 mRNA grain density in neurons counted at each position compared with neurons on control sections from that position on the same slide (Student's $t$ test, $p \leq$ 0.05). There is also a significant effect of distance from the epicenter on the relative decrease of GluR2 mRNA (repeat-measures ANOVA, $p=$ $0.001)$. The dotted lines indicate statistically similar effects at $\pm 2, \pm 4, \pm 8$ $\mathrm{mm}$, and -15 to $-20 \mathrm{~mm}$, whereas between the points indicated by the lines the relative levels of GluR2 mRNA are significantly different (Tukey post hoc, $p \leq 0.05)$.

appear to change in the thoracic cord after SCI (S. Grossman, unpublished data).

\section{Reduced GluR2: harbinger of cell death or indication of plasticity?}

Decreased GluR2 mRNA and protein suggests assembly of AMPA receptors lacking GluR2. Such receptors could promote

neurotoxicity through excessive $\mathrm{Ca}^{2+}$ influx (Eastwood et al., 1997) and elevation of free intracellular $\mathrm{Ca}^{2+}$ levels (Ciutat et al., 1995; Jia et al., 1996). In experimental ischemia, levels of GluR2 decrease to $0-20 \%$ of normal levels in cells destined to die (Heurteaux et al., 1994), leading to the "GluR2 hypothesis" (Bennett et al., 1996; Pellegrini-Giampietro et al., 1997), which suggests that the downregulation of GluR2 results in increases in intracellular levels of $\mathrm{Ca}^{2+}$ that cause cell death.

However, aspects of the GluR2 hypothesis have recently been challenged (Ben-Ari and Khrestchatisky, 1998). Our results also argue against it in the context of SCI. The downregulation of GluR2 protein and mRNA that we observed was in preserved tissue and healthy-appearing motor neurons at $24 \mathrm{hr}$ and persisted at 1 month after SCI. It appears unlikely that the decreased GluR2 that we saw presaged the death of these neurons. However, the reduction that we observed was less than that seen in brain ischemia. Perhaps a more pronounced decrease in GluR2 expression occurred earlier after SCI, in neurons that did not survive to $24 \mathrm{hr}$ after injury.

Decreased GluR4 mRNA after SCI must also be considered. GluR4 mRNA has been shown to increase after oxygen glucose deprivation (Ying et al., 1997), perhaps serving to limit postischemic excitation by the increased desensitization properties of GluR4 flop-containing receptors. The chronic decrease in GluR4 mRNA that we see may contribute to altered excitability of the VMNs after SCI. Future experiments will be needed to evaluate this possibility.

Glutamate subunit changes have also been associated with synaptic plasticity (Garraghty and Muja, 1996; Kaczmarek et al., 1997). Synaptic strengthening can occur by activation of $\mathrm{Ca}^{2+}$ permeable AMPA receptors (Gu et al., 1996) that can form when GluR2 expression is decreased (Gorter et al., 1997). Furthermore, GluR2 knockout mice demonstrate a $150 \%$ increase in synaptic efficacy along with a ninefold increase in relative $\mathrm{Ca}^{2+}$ permeability (Jia et al., 1996). The downregulation of GluR2 expression in healthy-appearing neurons at $24 \mathrm{hr}$ after SCI suggests possible $\mathrm{Ca}^{2+}$-mediated synaptic plasticity in these neurons.

\section{Population differences in IML neurons and VMNs in response to $\mathrm{SCl}$}

A novel finding in the current study was the different alterations in AMPA subunit expression in IML neurons and VMNs after SCI. Both populations of neurons are cholinergic and arise developmentally at the same time from common areas of the ventricular zone, presumably from a common cellular precursor (Phelps et al., 1991). However, they respond to SCI differently with respect to alterations in the expression of AMPA receptor subunits. It is tempting to speculate that differences seen in response to SCI may be related to other recognized differences in these two neuronal populations. IML neurons and VMNs differ in vulnerability to developmental cell death (Wetts, 1998), NMDA-induced excitotoxicity (Annis and Vaughn, 1998), and amyotrophic lateral sclerosis (ALS) (Wetts and Vaughn, 1996). In each of these situations VMNs are more vulnerable. Their vulnerability to neurodegeneration may be caused by their normally low expression of GluR2 (Furuyama et al., 1993; Tolle et al., $1993)$, reflected in the liberal number $(80 \%)$ of large motor neurons that are permeable to divalent cations (Carriedo et al., 1996). On the other hand, experimental mouse models of ALS, such as superoxide dismutase- 1 transgenic mice (Morrison et al., 1998), show no difference from controls in GluR2 distribution in vulnerable and nonvulnerable cell populations in the spinal cord 
(Morrison et al., 1998). It is possible that baseline GluR2 distribution does not determine the selective vulnerability of certain cell populations to excitotoxic death as much as the alterations in levels of GluR2 in response to insults. Our results showing a preferential susceptibility of VMNs to GluR2 downregulation, not seen in IML neurons, support this hypothesis.

The ratio of GluR2 to GluR1 is commonly used to predict the fraction of receptors that are calcium permeable (Burnashev, 1996; Pellegrini-Giampietro et al., 1992b). Using this ratio, we postulate that IML neurons may have an increased ratio after SCI, suggesting less calcium permeability, whereas VMNs may have a decreased ratio, suggesting more calcium permeability.

\section{Potential functional-behavioral consequences of altered AMPA receptors}

After incomplete SCI there is an initial period of spinal shock when all reflexes are suppressed (Beattie et al., 1993), with absence of hindlimb locomotor and reflex activity (Gale et al., 1985). In the days and weeks after injury, animals progressively recover hindlimb use and reflexes and enter into a stage of hyperreflexia. The hyperreflexia that develops may be attributable to disruption of descending axons that previously inhibited reflexes, to circuitry changes over time after SCI, or to increased intrinsic excitability of the motoneurons (Thompson et al., 1992).

The downregulation of GluR2 and other changes we see distally at 1 month after SCI may contribute to chronic hyperreflexia. If the downregulation of GluR2 was causally related to altered reflexes in the distal spinal cord, we would expect a similar timeline. Interestingly, lumbar reflex thresholds are only slightly reduced at $6 \mathrm{~d}$ after contusion but are significantly reduced by 1 month after injury (Thompson et al., 1992), when we see significant GluR2 downregulation in VMNs in the lumbar enlargement.

The use of antisense GluR2 oligonucleotides, however, results in neurons with transiently lower GluR2 that are less excitable (d'Aldin et al., 1997). GluR2 knockout mice do not show altered neuronal excitability (Jia et al., 1996). These mice have compensatory mechanisms that may affect their excitability: the ratio of NMDA to AMPA receptors is significantly higher than normal. Overall excitability of a cell depends on more than AMPA receptors. It will be important to determine not only the composition of assembled receptors but also the ratio of NMDA to AMPA receptors in the lumbar cord to investigate the potential contribution of altered glutamate receptors to hyperreflexia after SCI.

In conclusion, our results show population-specific and longlasting changes in AMPA receptor subunit expression, which if translated into functional receptors may alter the response of neurons in the spinal cord to glutamate after SCI. These alterations may contribute not only to acute neuropathological consequences of injury, but they may also be partially responsible for the altered functional state of preserved tissue chronically after SCI. Understanding the mechanisms that underlie these alterations and how they affect neurotransmission in the injured spinal cord may lead to novel therapies to enhance function after SCI.

\section{REFERENCES}

Annis CM, Vaughn JE (1998) Differential vulnerability of autonomic and somatic motor neurons to $N$-methyl-D-aspartate-induced excitotoxicity. Neuroscience 83:239-249.

Aronica EM, Gorter JA, Grooms S, Kessler JA, Bennett MVL, Zukin RS, Rosenbaum DM (1998) Aurintricarboxylic acid prevents GluR2 mRNA down-regulation and delayed neurodegeneration in hippocampal CA1 neurons of gerbil after global ischemia. Proc Natl Acad Sci USA 95:7115-7120.

Basso DM, Beattie MS, Bresnahan JC (1995) A sensitive and reliable locomotor rating scale for open field testing in rats. J Neurotrauma $12: 1-21$.

Beattie MS, Leedy MG, Bresnahan JC (1993) Evidence for alterations of synaptic inputs to sacral spinal reflex circuits after spinal cord transsection in the cat. Exp Neurol 123:35-50.

Ben-Ari Y, Khrestchatisky M (1998) The GluR2 (GluRB) hypothesis in ischemia: missing links. Trends Neurosci 21:241-242.

Bennett MV, Pellegrini-Giampietro DE, Gorter JA, Aronica E, Connor JA, Zukin RS (1996) The GluR2 hypothesis: Ca $(++)$-permeable AMPA receptors in delayed neurodegeneration. Cold Spring Harb Symp Quant Biol 61:373-384.

Burnashev N (1996) Calcium permeability of glutamate-gated channels in the central nervous system. Curr Opin Neurobiol 6:311-317.

Carriedo SG, Yin HZ, Weiss JH (1996) Motor neurons are selectively vulnerable to AMPA/kainate receptor-mediated injury in vitro. J Neurosci 16:4069-4079.

Choi DW (1994) Glutamate receptors and the induction of excitotoxic neuronal death. Prog Brain Res 100:47-51.

Ciutat D, Esquerda JE, Caldero J (1995) Evidence for calcium regulation of spinal cord motoneuron death in the chick embryo in vivo. Brain Res Dev Brain Res 86:167-179.

Crowe MJ, Bresnahan JC, Shuman SL, Masters JN, Beattie MS (1997) Apoptosis and delayed degeneration after spinal cord injury in rats and monkeys [Erratum (1997) 3:240]. Nat Med 3:73-76.

d'Aldin CG, Ruel J, Assie R, Pujol R, Puel JL (1997) Implication of NMDA type glutamate receptors in neural regeneration and neoformation of synapses after excitotoxic injury in the guinea pig cochlea. Int J Dev Neurosci 15:619-629.

Demediuk P, Daly MP, Faden AI (1989) Effect of impact trauma on neurotransmitter and nonneurotransmitter amino acids in rat spinal cord [Erratum (1990) 54:724-725]. J Neurochem 52:1529-1536.

Eastwood SL, Burnet PW, Harrison PJ (1997) GluR2 glutamate receptor subunit flip and flop isoforms are decreased in the hippocampal formation in schizophrenia: a reverse transcriptase-polymerase chain reaction (RT-PCR) study. Brain Res Mol Brain Res 44:92-98.

Faden AI, Simon RP (1988) A potential role for excitotoxins in the pathophysiology of spinal cord injury. Ann Neurol 23:623-626.

Faden AI, Lemke M, Simon RP, Noble LJ (1988) $N$-methyl-D-aspartate antagonist MK801 improves outcome following traumatic spinal cord injury in rats: behavioral, anatomic, and neurochemical studies. J Neurotrauma 5:33-45.

Faden AI, Ellison JA, Noble LJ (1990) Effects of competitive and noncompetitive NMDA receptor antagonists in spinal cord injury. Eur J Pharmacol 175:165-174.

Furuyama T, Kiyama H, Sato K, Park HT, Maeno H, Takagi H, Tohyama M (1993) Region-specific expression of subunits of ionotropic glutamate receptors (AMPA-type, KA-type and NMDA receptors) in the rat spinal cord with special reference to nociception. Brain Res Mol Brain Res 18:141-151.

Gale K, Kerasidis H, Wrathall JR (1985) Spinal cord contusion in the rat: behavioral analysis of functional neurologic impairment. Exp Neurol 88:123-134.

Garraghty PE, Muja N (1996) NMDA receptors and plasticity in adult primate somatosensory cortex. J Comp Neurol 367:319-326.

Gomez-Pinilla F, Tram H, Cotman CW, Nieto-Sampedro M (1989) Neuroprotective effect of M K-801 and U-50488H after contusive spinal cord injury. Exp Neurol 104:118-124.

Gorter JA, Petrozzino JJ, Aronica EM, Rosenbaum DM, Opitz T, Bennett MV, Connor JA, Zukin RS (1997) Global ischemia induces downregulation of Glur2 mRNA and increases AMPA receptormediated $\mathrm{Ca}^{2+}$ influx in hippocampal CA1 neurons of gerbil. J Neurosci 17:6179-6188.

Gu JG, Albuqueue C, Lee CJ, MacDermott AB (1996) Synaptic strengthening through activation of $\mathrm{Ca} 2+$ permeable AMPA receptors. Nature 381:793-796.

Heurteaux C, Lauritzen I, Widmann C, Lazdunski M (1994) Glutamateinduced overexpression of NMDA receptor messenger RNAs and protein triggered by activation of AMPA/kainate receptors in rat hippocampus following forebrain ischemia. Brain Res 659:67-74.

Hollmann M, Heinemann S (1994) Cloned glutamate receptors. Annu Rev Neurosci 17:31-108.

Hollmann M, Hartley M, Heinemann S (1991) Ca2+ permeability of KA-AMPA-gated glutamate receptor channels depends on subunit composition. Science 252:851-853.

Hugon J, Vallet JM, Spencer PS, Leboutet MJ, Barthe D (1986) Kainic 
acid induces early and late delayed degenerative neuronal changes in rat spinal cord. Neurosci Lett 104:258-262.

Jakowec MW, Yen L, Kalb RG (1995) In situ hybridization analysis of AMPA receptor subunit gene expression in the developing rat spinal cord. Neuroscience 67:909-920.

Jia Z, Agopyan N, Miu P, Xiong Z, Henderson J, Gerlai R, Taverna FA, Velumian A, MacDonald J, Carlen P, Abramow-Newerly W, Roder J (1996) Enhanced LTP in mice deficient in the AMPA receptor GluR2. Neuron 17:945-956.

Kaczmarek L, Kossut M, Skangiel-Kramska J (1997) Glutamate receptors in cortical plasticity: molecular and cellular biology. Physiol Rev 77:217-255.

Keinanen K, Wisden W, Sommer B, Werner P, Herb A, Verdoorn TA, Sakmann B, Seeburg PH (1990) A family of AMPA-selective glutamate receptors. Science 249:556-560.

Liu D, Thangnipon W, McAdoo DJ (1991) Excitatory amino acids rise to toxic levels upon impact injury to the rat spinal cord. Brain Res 547:344-348

Liu XZ, Xu XM, Hu R, Du C, Zhang SX, McDonald JW, Dong HX, Wu YJ, Fan GS, Jacquin MF, Hsu CY, Choi DW (1997) Neuronal and glial apoptosis after traumatic spinal cord injury. J Neurosci 17:5395-5406.

Luo J, Wang YH, Yasuda RP, Dunah AW, Wolfe BB (1997) The majority of NMDA receptor complexes in adult rat cerebral cortex contain at least three different subunits (NR1/NR2A/NR2B). Mol Pharmacol $51: 79-86$.

McNair C, Baxter G, Kerr R, Maxwell D (1998) Glutamate receptor subunits associated with rat sympathetic preganglionic neurons. Neurosci Lett 256:29-32.

Monyer H, Sprengel R, Schoepfer R, Herb A, Higuchi M, Lomeli H, Burnashev N, Sakmann B, Seeburg PH (1992) Heteromeric NMDA receptors: molecular and functional distinction of subtypes. Science 256:1217-1221.

Morrison BM, Janssen WG, Gordon JW, Morrison JH (1998) Light and electron microscopic distribution of the AMPA receptor subunit, GluR2, in the spinal cord of control and G86R mutant superoxide dismutase transgenic mice. J Comp Neurol 395:523-534.

Noble LJ, Wrathall JR (1985) Spinal cord contusion in the rat: morphometric analyses of alterations in the spinal cord. Exp Neurol 88:135-149.

Noble LJ, Wrathall JR (1989) Correlative analyses of lesion development and functional status after graded spinal cord contusive injuries in the rat. Exp Neurol 103:34-40.

Panjabi MM, Wrathall JR (1988) Biomechanical analysis of experimental spinal cord injury and functional loss. Spine 13:1365-1370.

Panter SS, Yum SW, Faden AI (1990) Alteration in extracellular amino acids after traumatic spinal cord injury. Ann Neurol 27:96-99.

Pellegrini-Giampietro DE, Zukin RS, Bennett MV, Cho S, Pulsinelli WA (1992a) Switch in glutamate receptor subunit gene expression in CA1 subfield of hippocampus following global ischemia in rats [Erratum (1993) 90:780]. Proc Natl Acad Sci USA 89:10499-10503.

Pellegrini-Giampietro DE, Bennett MVL, Zukin RS (1992b) Are calcium permeable AMPA/kainate receptors more abundant in immature brain? Neurosci Lett 144:65-69.

Pellegrini-Giampietro DE, Gorter JA, Bennett MV, Zukin RS (1997) The GluR2 (GluR-B) hypothesis: $\mathrm{Ca}(2+)$-permeable AMPA receptors in neurological disorders. Trends Neurosci 20:464-470.

Petralia RS, Wang YX, Mayat E, Wenthold RJ (1997) Glutamate receptor subunit 2-selective antibody shows a differential distribution of calcium-impermeable AMPA receptors among populations of neurons. J Comp Neurol 385:456-476.

Phelps PE, Barber RP, Vaughn JE (1991) Embryonic development of choline acetyltransferase in thoracic spinal motor neurons: somatic and autonomic neurons may be derived from a common cellular group. J Comp Neurol 307:77-86.

Raines A, Dretchen KL, Marx K, Wrathall JR (1988) Spinal cord contusion in the rat: somatosensory evoked potentials as a function of graded injury. J Neurotrauma 5:151-160.

Rosenberg LJ, Teng YD, Wrathall JR (1999) 2,3-Dihydroxy-6-nitro-7sulfamoyl-benzo(f)quinoxaline reduces glial loss and acute white matter pathology after experimental spinal cord contusion. J Neurosci 19:464-475

Sheardown MJ, Nielsen EO, Hansen AJ, Jacobsen P, Honore T (1990) 2,3-Dihydroxy-6-nitro-7-sulfamoyl-benzo(F)quinoxaline: a neuroprotectant for cerebral ischemia. Science 247:571-574.
Shuman SL, Bresnahan JC, Beattie MS (1997) Apoptosis of microglia and oligodendrocytes after spinal cord contusion in rats. J Neurosci Res 50:798-808.

Sommer B, Keinanen K, Verdoorn TA, Wisden W, Burnashev N, Herb A, Kohler M, Takagi T, Sakmann B, Seeburg PH (1990) Flip and flop: a cell-specific functional switch in glutamate-operated channels of the CNS. Science 249:1580-1585.

Tachibana M, Wenthold RJ, Morioka H, Petralia RS (1994) Light and electron microscopic immunocytochemical localization of AMPAselective glutamate receptors in the rat spinal cord. J Comp Neurol 344:431-454

Teng YD, Wrathall JR (1997) Local blockade of sodium channels by tetrodotoxin ameliorates tissue loss and long-term functional deficits resulting from experimental spinal cord injury. J Neurosci 17:4359-4366.

Teng YD, Mocchetti I, Wrathall JR (1998) Basic and acidic fibroblast growth factors protect spinal motor neurones in vivo after experimental spinal cord injury. Eur J Neurosci 10:798-802.

Thompson FJ, Reier PJ, Lucas CC, Parmer R (1992) Altered patterns of reflex excitability subsequent to contusion injury of the rat spinal cord. J Neurophysiol 68:1473-1486.

Tolle TR, Berthele A, Zieglgansberger W, Seeburg PH, Wisden W (1993) The differential expression of 16 NMDA and non-NMDA receptor subunits in the rat spinal cord and in periaqueductal gray. J Neurosci 13:5009-5028.

Tomiyama M, Rodriguez-Puertas R, Cortes R, Christnacher A, Sommer B, Pazos A, Palacios JM, Mengod G (1996) Differential regional distribution of AMPA receptor subunit messenger RNAs in the human spinal cord as visualized by in situ hybridization. Neuroscience 75:901-915.

Towbin H, Staehelin T, Gordon J (1979) Electrophoretic transfer of proteins from polyacrylamide gels to nitrocellulose sheets: procedure and some applications. Proc Natl Acad Sci USA 76:4350-4354.

von Euler M, Seiger A, Holmberg L, Sundstrom E (1994) NBQX, a competitive non-NMDA receptor antagonist, reduces degeneration due to focal spinal cord ischemia. Exp Neurol 129:163-168.

Wang YH, Bosy TZ, Yasuda RP, Grayson DR, Vicini S, Pizzorusso T, Wolfe BB (1995) Characterization of NMDA receptor subunit-specific antibodies: distribution of NR2A and NR2B receptor subunits in rat brain and ontogenic profile in the cerebellum. J Neurochem 65:176-183.

Wenthold RJ, Yokotani N, Doi K, Wada K (1992) Immunochemical characterization of the non-NMDA glutamate receptor using subunitspecific antibodies. Evidence for a hetero-oligomeric structure in rat brain. J Biol Chem 267:501-507.

Wenthold RJ, Petralia RS, Blahos J, Niedzielski AS (1996) Evidence for multiple AMPA receptor complexes in hippocampal CA1/CA2 neurons. J Neurosci 16:1982-1989.

Wetts R (1998) Differences in developmental cell death between somatic and autonomic motor neurons of the rat spinal cord. J Comp Neurol 396:483-492.

Wetts R, Vaughn JE (1996) Differential vulnerability of two subsets of spinal motor neurons in amyotrophic lateral sclerosis. Exp Neurol $141: 248-255$.

Wrathall JR, Pettegrew RK, Harvey F (1985) Spinal cord contusion in the rat: production of graded, reproducible, injury groups. Exp Neurol 88:108-122.

Wrathall JR, Choiniere D, Teng YD (1994) Dose-dependent reduction of tissue loss and functional impairment after spinal cord trauma with the AMPA/kainate antagonist NBQX. J Neurosci 14:6598-6607.

Wrathall JR, Teng YD, Choiniere D (1996) Amelioration of functional deficits from spinal cord trauma with systemically administered NBQX, an antagonist of non- $N$-methyl-D-aspartate receptors. Exp Neurol 137:119-126.

Wrathall JR, Teng YD, Marriott R (1997) Delayed antagonism of AMPA/kainate receptors reduces long-term functional deficits resulting from spinal cord trauma. Exp Neurol 145:565-573.

Wrathall JR, Li W, Hudson LD (1998) Myelin gene expression after contusive spinal cord injury. J Neurosci 18:8780-8793.

Ying HS, Weishaupt JH, Grabb M, Canzoniero LMT, Sensi SL, Sheline CT, Monyer H, Choi DW (1997) Sublethal oxygen glucose deprivation alters hippocampal neuronal AMPA receptor expression and vulnerability to kainate-induced death. J Neurosci 17:9536-9544. 